\title{
Point of View
}

\section{An overview of the Sixth International Conference on the Comparative Biology of Monocotyledons - Monocots VI - Natal, Brazil, 2018}

\author{
Leonardo M. Versieux ${ }^{1,20,38}$, Alice Calvente ${ }^{1,21}$, Fernanda Antunes Carvalho ${ }^{1,2}$, Carlos Roberto Fonseca ${ }^{1,22}$, \\ Juliana Espada Lichston ${ }^{1,23}$, Eduardo Voigt ${ }^{1,24}$, Anderson Lopes Fontes ${ }^{1,25}$, Alan Roque ${ }^{1,26}$, Joseph Hill \\ Williams $^{1,3}$, Reyjane Patrícia de Oliveira ${ }^{4,27}$, Pedro Lage Viana ${ }^{5}$, Helenice Mercier ${ }^{6}$, Clarisse Palma-Silva ${ }^{7}$, \\ Tânia Wendt ${ }^{8,28}$, Lívia Godinho Temponi ${ }^{9}$, Ivanilza Moreira de Andrade ${ }^{10}$, Aline Oriani ${ }^{11,29}$, Thales D. \\ Leandro $^{11,30}$, Edlley Max Pessoa ${ }^{12}$, Adriana Pinheiro Martinelli ${ }^{13}$, Thiago André ${ }^{14}$, Ana Maria Benko- \\ Iseppon ${ }^{15,31}$, Cássio van den Berg ${ }^{4,32}$, Cynthia Fernandes Pinto da Luz ${ }^{16,33}$. Francisco Prosdocimi ${ }^{8,34}$, \\ Jomar G. Jardim ${ }^{17}$, Marccus Alves ${ }^{15,35}$, Maria das Graças Lapa Wanderley ${ }^{16,36}$, Rafaela Campostrini \\ Forzza $^{18}$, Vera Lucia Scatena ${ }^{11,37}$ \& Lynn G. Clark $^{19}$
}

\begin{abstract}
In this paper we present an overview of the abstracts, scientific and social programs, field trips, and achievements in terms of participant number, represented countries, sponsorships, and themes treated during the Sixth International Conference on the Comparative Biology of Monocotyledons that took place in Natal, Brazil, October $7^{\text {th }}-12^{\text {th }} 2018$. Some comments received by the organizers and a few suggestions for organizers of the next meeting, in Costa Rica, are also provided. The conference's complete abstract book was published and provide additional information.
\end{abstract}

Key words: Araceae, botany, Bromeliaceae, monocots, Poaceae.

\footnotetext{
${ }^{1}$ Universidade Federal do Rio Grande do Norte, Depto. Botânica e Zoologia, Natal, RN, Brazil.

${ }^{2}$ Universidade Federal de Minas Gerais, Depto. Biologia Geral, Belo Horizonte, MG, Brazil. ORCID: <https://orcid.org/0000-0002-3485-0797>.

${ }^{3}$ University of Tennessee, Department of Ecology and Evolutionary Biology, Knoxville, Tennessee, U.S.A. ORCID: <https://orcid.org/0000-0002-1206-5667>.

${ }^{4}$ Universidade Estadual de Feira de Santana, Depto. Ciências Biológicas, Feira de Santana, BA, Brazil.

${ }^{5}$ Museu Paraense Emílio Goeldi, Belém, PA, Brazil. ORCID: <https://orcid.org/0000-0001-5044-0758>.

${ }^{6}$ Universidade de São Paulo, Depto. Botânica, São Paulo, SP, Brazil. ORCID: <https://orcid.org/0000-0001-7431-8837>.

${ }^{7}$ Universidade Estadual de Campinas, Depto. Biologia Vegetal, Campinas, SP, Brazil. ORCID: <https://orcid.org/0000-0003-0192-5489>.

${ }^{8}$ Universidade Federal do Rio de Janeiro, Centro de Ciências da Saúde, Rio de Janeiro, RJ, Brazil.

${ }^{9}$ Universidade Estadual do Oeste do Paraná, campus Cascavel, Cascavel, PR, Brazil. ORCID: <https://orcid.org/0000-0003-0449-2703>.

${ }^{10}$ Universidade Federal do Piauí, campus Ministro Reis Velloso, Parnaíba, PI, Brazil. ORCID: <https://orcid.org/0000-0001-6059-8540>.

${ }^{11}$ Universidade Estadual Paulista Júlio de Mesquita Filho - UNESP, Depto. Biodiversidade, Rio Claro, SP, Brazil.

${ }^{12}$ Universidade Federal de Mato Grosso, Depto. Botânica e Ecologia, Cuiabá, MT, Brazil. ORCID: <https://orcid.org/0000-0003-3800-8684>

${ }^{13}$ Universidade de São Paulo, Centro de Energia Nuclear na Agricultura, Piracicaba, SP, Brazil. ORCID: <https://orcid.org/0000-0003-1278-3930>.

${ }^{14}$ UUniversidade Federal do Oeste do Pará, Inst. Biodiversidade e Florestas, Santarém, PA, Brazil. ORCID: < https://orcid.org/0000-0003-4148-3662>.

${ }^{15}$ Universidade Federal de Pernambuco, Centro de Ciências Biológicas, Recife, PE, Brazil.

${ }^{16}$ Instituto de Botânica, São Paulo, SP, Brazil.

${ }^{17}$ Universidade Federal do Sul da Bahia, Centro de Formação em Ciências Agroflorestais, Itabuna, BA, Brazil. ORCID: <https://orcid.org/0000-0002-5094-0514>.

${ }^{18}$ Instituto de Pesquisas Jardim Botânico do Rio de Janeiro, Rio de Janeiro, RJ, Brazil. ORCID: <https://orcid.org/0000-0002-7035-9313>.

${ }^{19}$ Iowa State University, Department of Ecology, Evolution, and Organismal Biology, Ames, Iowa, U.S.A. ORCID: <https://orcid.org/0000-0001-5564-4688>

${ }^{20}$ ORCID: $<$ https://orcid.org/0000-0003-1560-3691>. ${ }^{21}$ ORCID: $<$ https://orcid.org/0000-0001-5884-508X>. ${ }^{22}$ ORCID: $<$ https://orcid.org/0000-0003-0292-0399> >. ORCID: <https://orcid.org/0000-0002-4042-4524>. ${ }^{24}$ ORCID: <https://orcid.org/0000-0003-0481-1129>. ${ }^{25}$ ORCID: $<$ https://orcid.org/0000-0002-7101-582X> $>{ }^{26}$ ORCID: $<$ https://orcid.org/0000-0001-7762-7774>. ${ }^{27}$ ORCID: <https://orcid.org/0000-0001-8831-2882>. ${ }^{28}$ ORCID: <https://orcid.org/0000-0001-6411-0354>. ${ }^{29}$ ORCID: <https:// orcid.org/0000-0003-0843-1254>.$^{30}$ ORCID: <https://orcid.org/0000-0002-5800-5432>. ${ }^{31}$ ORCID: <https://orcid.org/0000-0002-0575-3197>. ${ }^{32}$ ORCID: $<$ https://orcid. org/0000-0001-5028-0686> $>{ }^{33}$ ORCID: <https://orcid.org/0000-0001-7908-155X >.${ }^{34}$ ORCID: <https://orcid.org/0000-0002-6761-3069>.${ }^{35}$ ORCID: <htps://orcid.org/ 0000-0001-9281-2257> ${ }^{36}$ ORCID: <htps://orcid.org/0000-0002-7294-6642>

${ }^{38}$ Author for correspondence: lversieux@yahoo.com.br
} 


\begin{abstract}
Resumo
Neste artigo nós apresentamos uma visão geral dos resumos, programação científica e social, viagens de campo e informações acerca do número de inscritos, países participantes, patrocínios e temas tratados durante a Sexta Conferência Internacional sobre Biologia Comparada de Monocotiledôneas, realizada em Natal, Brasil, de 7 a 12 de outubro de 2018. Alguns comentários recebidos pelos organizadores e sugestões para os organizadores do próximo Monocots, na Costa Rica, também são fornecidos. Este artigo complementa os dados publicados no livro de resumos, disponível no Repositório Digital da UFRN.
\end{abstract}

Palavras-chave: Araceae, botânica, Bromeliaceae, monocotiledôneas, Poaceae.

The International Conference on the Comparative Biology of Monocotyledons (Monocots) is one of the most important conferences for botanical science. Although originally focused on systematics and evolution - gathering mostly specialists from the fields of systematics and morphology - the Monocots conference has expanded its coverage and themes, which are currently addressed under a broader scope of comparative biology. Monocot conservation, biotechnology, ecology, and physiology are all growing topics within the conference, which is traditionally held every five years.

To date, this conference has been held six times: (i) 1993, Monocotyledon Systematics and Evolution, Royal Botanic Gardens, Kew, England (Rudall et al. 1995); (ii) 1998, International Conference on the Comparative Biology of Monocotyledons - Monocots II, Royal Botanic Gardens Sydney, Australia (Wilson \& Morrison 2000); (iii) 2003, Monocots III: The Third International Congress on the Comparative Biology of the Monocotyledons \& The Fourth International Symposium on Grass Systematics and Evolution, Rancho Santa Ana Botanic Garden, California, U.S.A. (Columbus et al. 2006, 2007); (iv) 2008, Monocots IV, University of Copenhagen, Denmark (Seberg et al. 2008); and (v) 2013, Monocots V, Fordham University hosted by The New York Botanical Garden, U.S.A. marked the 20th anniversary of the conference series (Campbell et al. 2017).

Then, after a significant attendance of Brazilians at the 2008 and 2013 conferences, a Brazilian host city proposal won the voting after the New York meeting. Under the motto "Monocots for all: building the whole from its parts", the $6^{\text {th }}$ International Conference on the Comparative Biology of Monocotyledons - Monocots VI was held at the Praiamar Natal Hotel \& Convention Center, in Natal, Northeastern Brazil, October $7^{\text {th }}-12^{\text {th }}, 2018$. It was the first time that Latin America hosted this important meeting.
The Monocots VI conference was organized by a multidisciplinary group of professors, technicians and students from the Universidade Federal do Rio Grande do Norte (UFRN, corresponding to the first nine authors of this paper) and by a Board of Counselors from different universities, botanic gardens, and research institutes in Brazil and abroad, namely: Adriana Pinheiro Martinelli (Plant biotechnology, Universidade de São Paulo, CENA, Piracicaba, São Paulo); Ana Maria Benko Iseppon (Molecular biology, Universidade Federal de Pernambuco); Cássio van den Berg (Plant systematics and genetics, Universidade Estadual de Feira de Santana, Bahia); Cynthia Fernandes Pinto da Luz (Palynology, Instituto de Botânica, São Paulo); Francisco Prosdocimi (Genomics and Bioinformatics, Universidade Federal do Rio de Janeiro); Joseph Williams Jr. (Plant evolutionary biology, The University of Tennessee, U.S.A.); Marccus Vinícius Alves (Plant systematics and floristics, Universidade Federal de Pernambuco); Maria das Graças Lapa Wanderley (Plant systematics and floristics, Instituto de Botânica, São Paulo); Rafaela Campostrini Forzza (Plant systematics and collections, Jardim Botânico do Rio de Janeiro); and Vera Lucia Scatena (Plant morphology, Universidade Estadual Paulista, Rio Claro, São Paulo). Also, 20 students from different levels of study, mostly from the UFRN Herbarium, worked during the event.

It was sponsored by the National Council for Scientific and Technological Development (CNPq), National Council for the Improvement of Higher Education (CAPES), and the Bromeliad Society International. Although not a formal sponsor, support from FAPESP (São Paulo Research Foundation) allowed several researchers from São Paulo State to attend the conference.

Considering the difficult moment that Brazilian science is going through in terms of funding cuts, the organizing committee approved, upon request, substantial discounts in registration fees for any unemployed professionals attending 
the conference or graduate students presenting talks in symposia. Students presenting their work in BromEvo 2 (see Versieux et al. 2020) were assisted by a grant from the Bromeliad Society International (BSI), whereas the $7^{\text {th }}$ International Symposium on Grass Systematics and Evolution was fully covered by the CAPES agency.

The scientific program was organized into themes and included keynote lectures, master classes, symposium talks, and poster presentations. The local committee was responsible for the conference development and scientific program, headed by Leonardo M. Versieux (chairman), Alice Calvente, Fernanda Antunes Carvalho, Carlos Roberto Fonseca, Eduardo Voigt, and Juliana Espada Lichston; field trip organizers were Jomar Gomes Jardim and Alan Roque; and Anderson Lopes Fontes organized herbarium management and visits. The organizing committee also counted on the experience of senior scientists who were particularly important during fundraising campaigns and in spreading open calls for symposia. The poster session was coordinated by a group of undergraduate and graduate students mostly from UFRN, who also worked in other capacities.

Five lunchtime keynote lectures were given during the main event: (i) Monday, October 8, by W. John Kress (Smithsonian Institution, U.S.A.): Monocots in the Anthropocene: species interactions in a rapidly changing world; (ii) Tuesday, October 9, by Lynn G. Clark (Iowa State University, U.S.A. - Special Visiting Researcher PVE/CNPq, Universidade Estadual de Feira de Santana, Bahia): 3D Biology: What we can learn from the "flat" grasses; (iii) Wednesday, October 10, by Christine Bacon (University of Gothenburg, Sweden): The road to evolutionary success: insights from Mauritia flexuosa; (iv) Thursday, October 11, by Gerhard Zotz (University Oldenburg, Germany \& Smithsonian Tropical Research Institute, Panama): A Sceptic's view on scientific "facts" and "concepts"; and (v) Friday, October 12, by Marccus Alves (Universidade Federal de Pernambuco, Brazil) in collaboration with Rafaela Campostrini Forzza (Jardim Botânico do Rio de Janeiro, Brazil): Monocots in the Brazilian Flora 2020: Facilitate access to plant diversity. In addition, there were two Master Classes: (i) Alexandre Antonelli (University of Gothenburg, Sweden, and Royal Botanic Gardens, Kew, England) together with Alexander Zizka (University of Gothenburg, Sweden) talked about recent advances and techniques to investigate biogeography with a focus on the Neotropics, and (ii) Thomas Givnish (University of Wisconsin, U.S.A.) presented a talk about phylogenetics, diversification analyses and molecular dating in the Bromeliaceae.

Almost 30 symposium talks were organized (see the following abstract book for the names of organizers $<$ https://repositorio.ufrn. br/handle/123456789/27097.) into topics and included discussions about: (1) Advances in the molecular phylogeny, systematics and evolution of Dioscoreales; (2) Advances in the anatomy of the large Poales clade; (3) Applied botany: Use of comparative data in horticulture, reproductive biology and systematics of Bromeliaceae; (4) Biogeography, ecology and macroevolution of grasses; (5) Ecophysiology of Bromeliaceae; (6) Evolution and diversification in Cyperaceae; (7) Genomic innovation through genome duplication: Examples from across Monocots; (8) Grass systematics and evolution - Plastome phylogenetics and the BOP Clade; (9) Grass systematics, evolution and development - The PACMAD clade; (10) Growing knowledge on monocot vegetative anatomy; (11) How can anatomy contribute to understanding monocot evolutionary patterns?; (12) III Symposium on Neotropical Araceae systematics and evolution; (13) III Symposium on Neotropical Araceae - floristics, morphology and evolution; (14) Linking macro- and microevolution in Bromeliaceae; (15) Monocot mats on Gondwanan inselbergs: binding taxonomy, ecology and molecular aspects under a biogeographic view; (16) Monocot phylogenomics I; (17) Monocot phylogenomics II - new insights on genome evolution, diversification and biogeography; (18) Monocots in society and tools to spread knowledge about monocots; (19) Neotropical Eriocaulaceae: answering evolutionary questions and supporting sustainability; (20) Orchid ecology and conservation, (21) Palms - The ecologically most diverse tropical plant family?; (22) Recent advances in Bromelioideae systematics, taxonomy, and evolution; (23) Recent advances in the systematics of Bromeliaceae; (24) Setaria as a model system for monocot development and biotechnology; (25) Systematics, evolution, and biogeography of Orchidaceae; (26) The next generation of research on the evolution of Crassulacean acid metabolism: integrating physiology, ecology, and genomics; (27) Understanding Amaryllidaceae evolution using different approaches; (28) Zingiberales I Evolution; and (29) Zingiberales II - Diversity. 
As part of the scientific program of the event, three parallel meetings were also held: (i) the $2^{\text {nd }}$ World Congress of Bromeliaceae Evolution - BromEvo 2, coordinated by Helenice Mercier, Clarisse Palma-Silva, Tânia Wendt, and Leonardo M. Versieux (Versieux et al. 2020); (ii) the $7^{\text {th }}$ International Symposium on Grass Systematics and Evolution, coordinated by Reyjane Patrícia de Oliveira, Lynn G. Clark, and Pedro Lage Viana; and (iii) the III Symposium on Neotropical Araceae, coordinated by Ivanilza Moreira de Andrade and Lívia Godinho Temponi. Along with the remaining scientific program, these parallel meetings facilitated a broad exchange of knowledge among the attendees, with a strong international component, thus increasing the visibility of Brazilian researchers within the botanical scientific community, but also promoting the UFRN Herbarium and botanical science at UFRN.

The Scientific Program was organized into themes and included Keynote Lectures, Master Classes, Symposium Talks and Poster presentations (Figs. 1-8). The main subject sessions of Monocots VI were: (i) Systematics, evolution, biogeography; (ii) Morphology, development and cellular biology; (iii) Physiology and biochemistry; (iv) Ecology and conservation; (v) Genetics, genomics and bioinformatics; (vi) Economic botany, plant breeding and agriculture; and (vii) Monocots in society and tools to divulge knowledge about monocots (Figs. 1; 2). Social
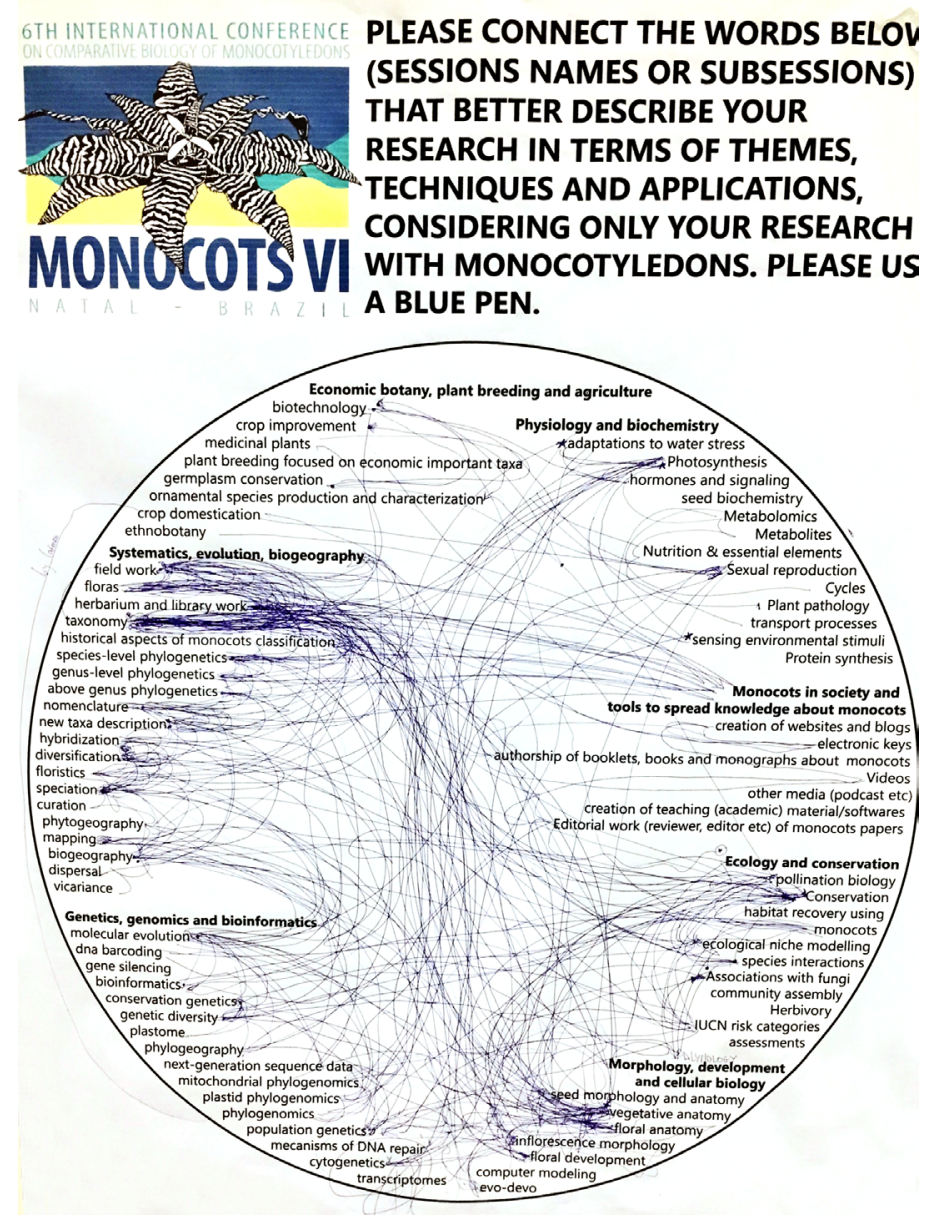

Figure 1 - Close-up of the poster describing the six main sessions of the Monocots VI plus thematic and technical words, allowing attendees to link the different areas covered by their work. Although Systematics, evolution and biogeography has the most concentrated lines, considerable intersections are observed among different fields of knowledge. The two areas with fewer marks include Economic botany, plant breeding and agriculture, and the popularizing scientific knowledge in different media, Monocots in society. 


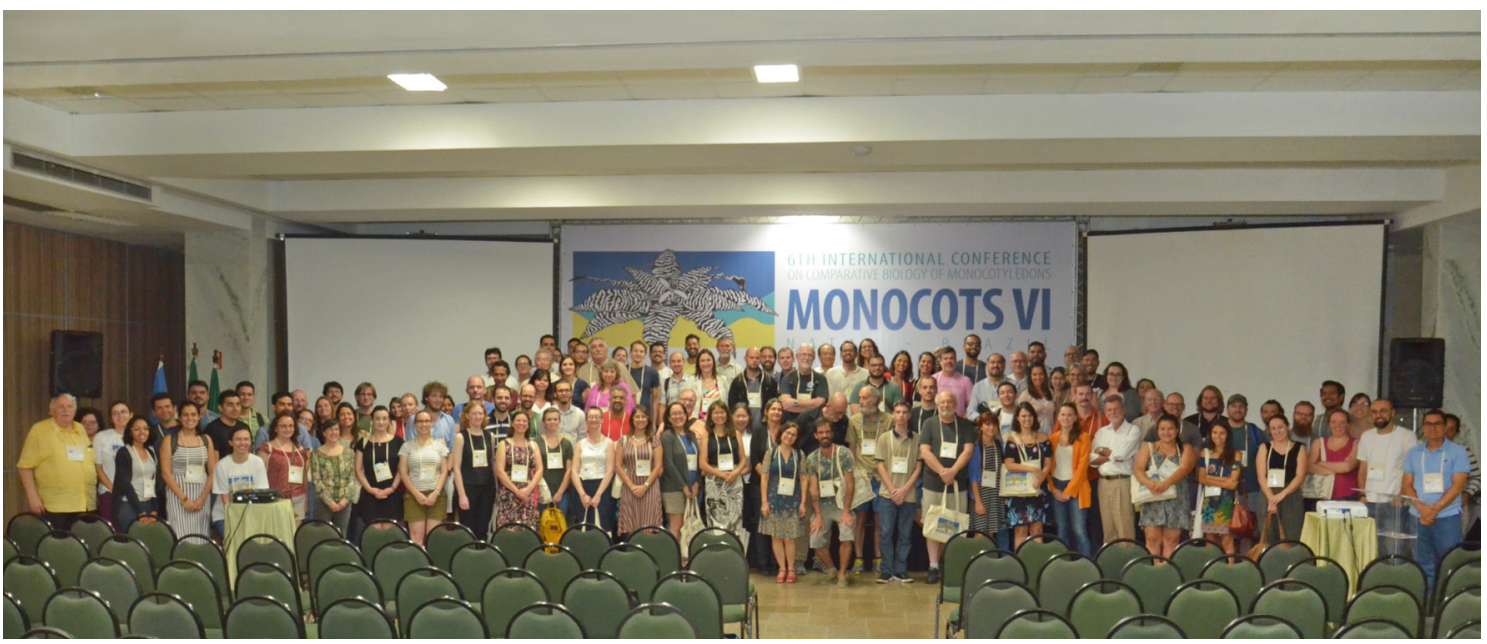

Figure 2 - Part of the attendees of Monocots VI after one of the keynote lectures.

events included an opening ceremony hosted by Joseph Williams and including the presence of UFRN's Deputy Dean, Prof. José Daniel Diniz Melo, a Gala Dinner, a Rock and Roll night, and a happy hour closure (Figs. 9-11).

The poster section, which was available during the evenings, totaled 216 posters presented, most of them in the session of systematics and morphology. It was an excellent opportunity to promote a strong interaction between students at various levels of study and researchers of significant international experience and prestige, since posters were placed in the main hall near all of the auditoria - offering thus a great chance for researchers to talk about their findings and network during coffee breaks or during any occasional encounter (Fig. 8).

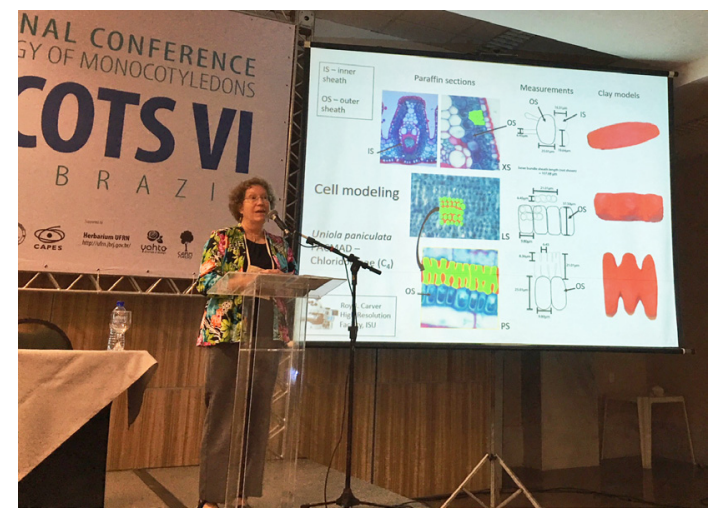

Figure 3 - Lynn Clark presenting her keynote lecture.
In addition, the meeting also offered, through the Programa de Pós-Graduação em Sistemática e Evolução - UFRN, before and after the conference, three Graduate courses (Figs. 12; 13): (i) Evolutionary Biogeography: Biodiversity data from field to yield, by Alexandre Antonelli and Alexander Zizka (University of Gothenburg, Gothenburg Global Biodiversity Centre, and iDiv); (ii) Evolution of Development of Plants: An introduction to comparative developmental biology and (iii) Evolution of plant reproduction: current topics, both by Joseph Williams Jr. (University of Tennessee, U.S.A.).

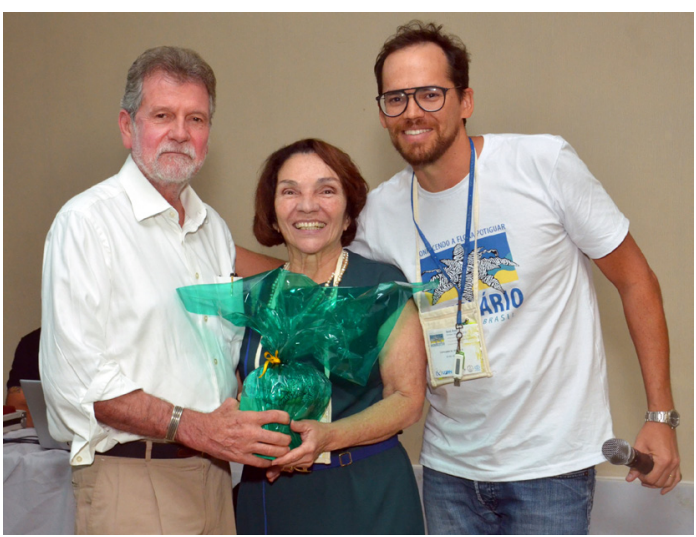

Figure 4 - Ana Maria Giulietti-Harley being honored for her outstanding achievements on monocot research during the Eriocaulaceae symposium, receiving a gift from W. John Kress and Leonardo Versieux. 


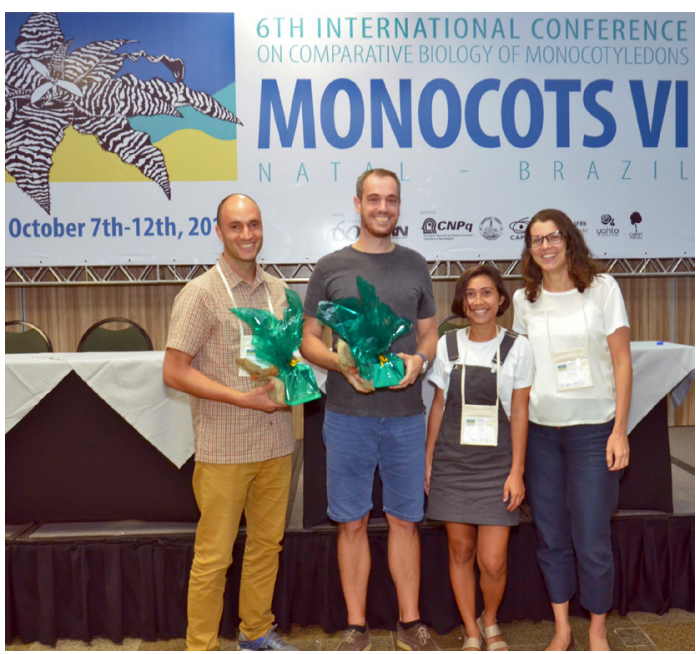

Figure 5 - Alexandre Antonelli and Alexander Zizka after their masterclass on biogeography receiving gifts from the organizers Ana Paula Siva and Alice Calvente.

During and after the scientific activities, it was possible to visit the Herbarium UFRN and participate in field trips, which were conducted in conservation areas in the state of Rio Grande do Norte, such as Parque Estadual das Dunas, Jenipabu, and the Seridó region. All these field trips were guided by professional botanists and included a broad international attendance (Figs. 14; 15).

Monocots VI had 397 attendees in total. Twenty-six countries were represented at the conference: Argentina (5), Australia (2), Austria (3), Brazil (272), Canada (3), China (3), Colombia (6), Costa Rica (1), Czech Republic (1), Denmark (3), Ecuador (1), France (1), Germany (11), India (6), Italy (1), Mexico (3), Netherlands (2), Norway

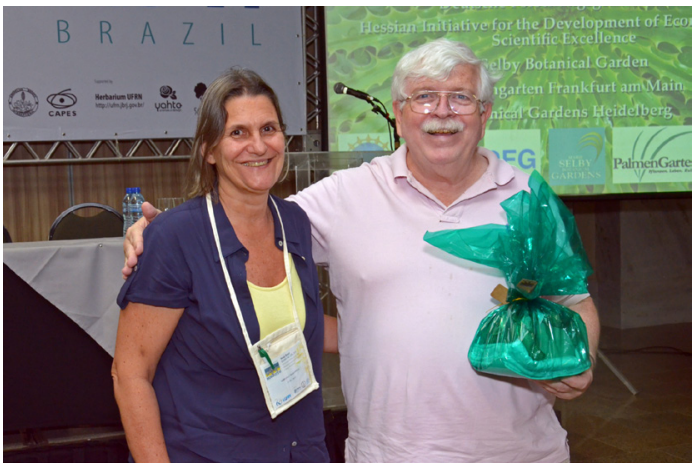

Figure 6 - Tom Givnish after his masterclass on Bromeliaceae receiving a gift from the organizer Adriana Martinelli.

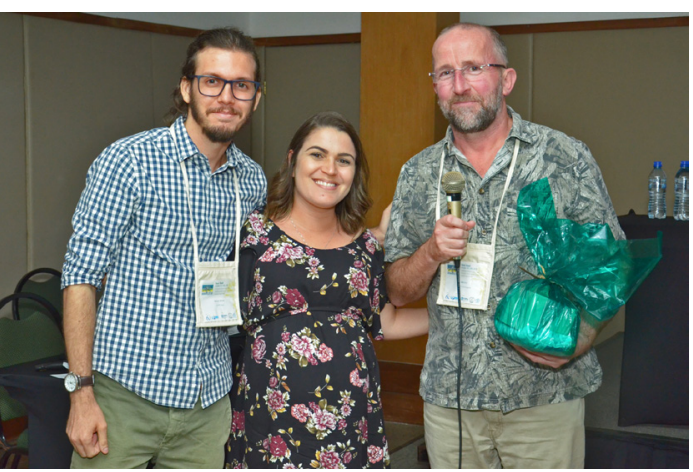

Figure 7 - Mike Fay being honored for his outstanding achievements on monocot research during the Orchidaceae symposium and receiving a gift from Edlley Pessoa and Lais Leite Barreto.

(2), Russian Federation (6), Spain (4), Sweden (2), Switzerland (5), Taiwan (1), United Kingdom (18), United States (32), and Uruguay (1), plus two registrations that left their countries and full address incomplete. As expected, Brazil leads the list, followed by the United States and the United Kingdom as the most represented countries.

After the conference, there was a virtual election to choose the host for the Monocots VII 2023. Three host proposals were presented: China (represented by Hangzhou University and the China Botanical Society), Costa Rica (represented by the Universidad de Costa Rica, Jardín Botánico Lankester), and U.S.A. (represented by The Marie Selby Botanical Gardens), totaling 211 electoral votes. The winning proposal, which received 145 votes, was submitted by Adam Karremans and colleagues from Costa Rica, followed by Sarasota (U.S.A) with 42 votes and Hangzhou (China) with 24 votes.

Some host candidates requested that the next election should be restricted to Asia and Africa, which have not hosted any Monocot conference so

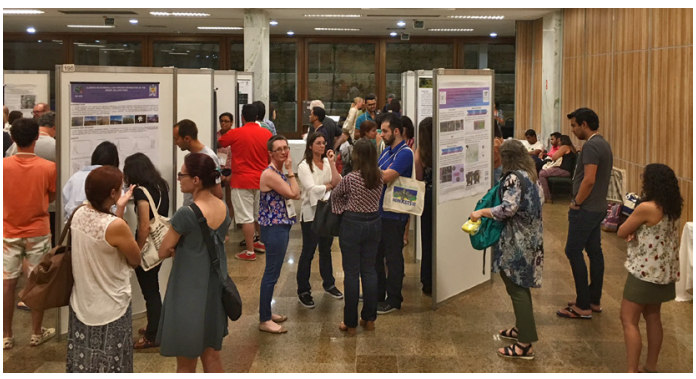

Figure 8 - Attendees during a poster session. 


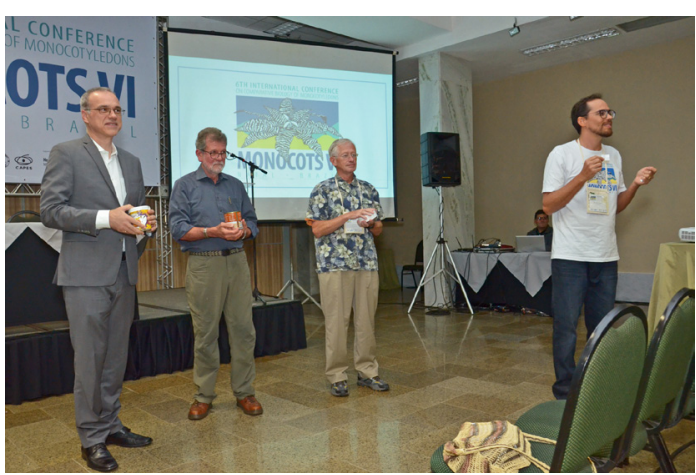

Figure 9 - Informal moment of the opening of the conference, in which free invitations for the Gala Dinner were "picked from the hat", by the UFRN's Dean, Prof. José Daniel Diniz Melo and the botanists W. John Kress, Gregory Brown, and Leonardo Versieux.

far. We believe that this is a good strategy to allow the conference to keep moving from one continent to another, enabling more attendees from different countries to participate. This is an interesting point of view, and we strongly recommend that countries interested in organizing / hosting the Monocots from those continents should discuss their candidatures in advance. Also, one suggestion received by us is to diminish the time from 5 to 4 years between each conference, what we also believe could be an interesting point for discussion in Costa Rica, in 2023. We thank all three host candidates for their important participation and wish very good luck to the Jardín Botánico Lankester and the Universidad de Costa Rica in setting up our next meeting.

Our feeling, supported by informal talks with colleagues who attended Monocots VI as well as by some commentaries which were publicized in social media and blogs (e.g., Woudstra \& Veltman 2018), is

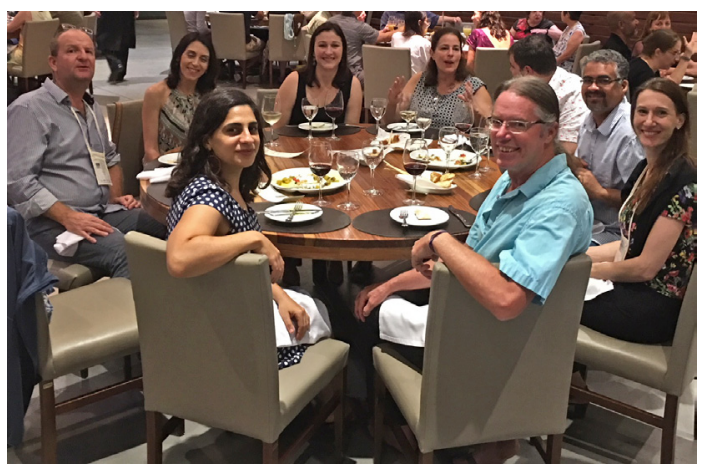

Figure 10 - Monocots VI attendees during the Gala dinner.

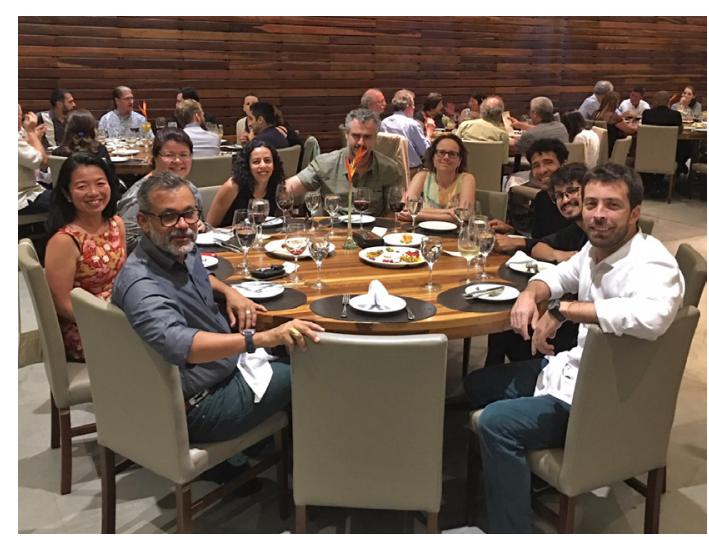

Figure 11 - Monocots VI attendees during the Gala dinner.

that Monocots VI accomplished its objectives, with an intense scientific and social program, diversified attendance, as well as growing and broadening the scope. Even participants from areas less represented, such as Economic Botany, Biotechnology, and Crops, left very positive comments, which suggest to us that the Monocots will become an even stronger and more integrative event for all subjects involving these important plants (Fig. 1). Also, a great number of young researchers were able to attend and network, several of them from UFRN (Fig. 16). Additionally, the herbarium UFRN was visited by a considerable number of specialists, what improved identifications of specimens, and received many book donations, increasing its library. We are thankful to all attendees, symposium organizers, speakers, students, and funding / supporting agencies (Fig. 16).

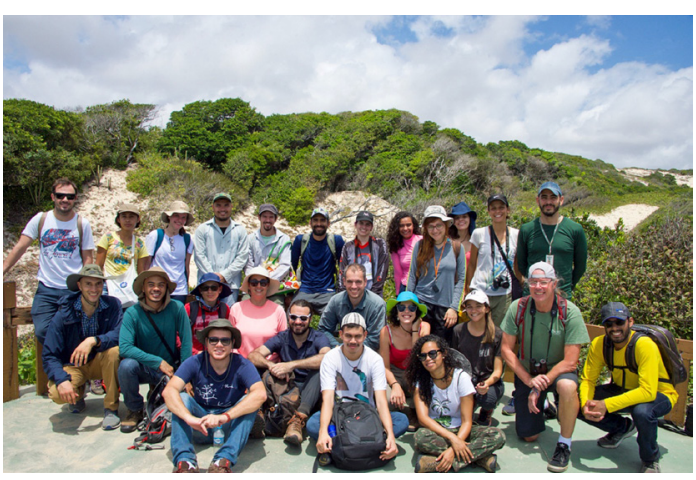

Figure 12 - Pre-conference graduate course on Biogeography (Prof. Alexandre Antonelli and Alexander Zizka) field trip to the restingas of Parque Estadual das Dunas. 


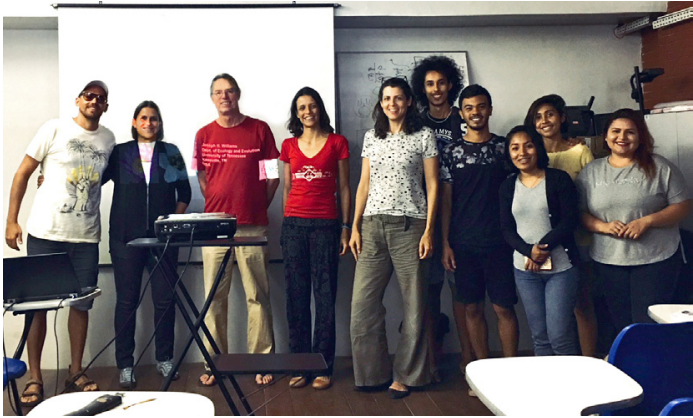

Figure 13 - Post-conference graduate course on Evolution of plant reproduction (Prof. Joe Williams).

All abstracts from Monocots VI (keynote lectures, master classes, symposium talks and poster presentations) are available in Versieux \& Clark (2019). Special issues focused on bromeliads and grasses papers presented during the event were published by the Botanical Journal of the Linnean Society. Official photos of the event may be seen in Instagram,@herbarioufrn.

\section{Acknowledgments}

We thank the Universidade Federal do Rio Grande do Norte (UFRN) for continuous support during the organization of this event. Earlier organizers of Monocots meetings, Lisa Campbell (NYBG) and Paula Rudall (RBGKew), for their incentive and supporting letters. Graduate programs of Sistemática e Evolução (UFRN), Recursos Genéticos Vegetais (UFRB), and Botânica (PPGBot, UEFS) also supported our candidature by sending letters. Gifts to keynote speakers were supplied by Yahto Aroma \& Design

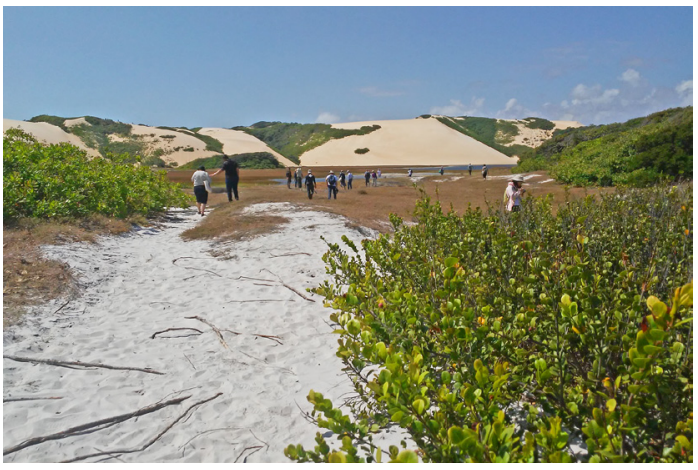

Figure 14 - Monocots VI attendees visiting the Environmental Protection Area of Jenipabu, in Extremoz.

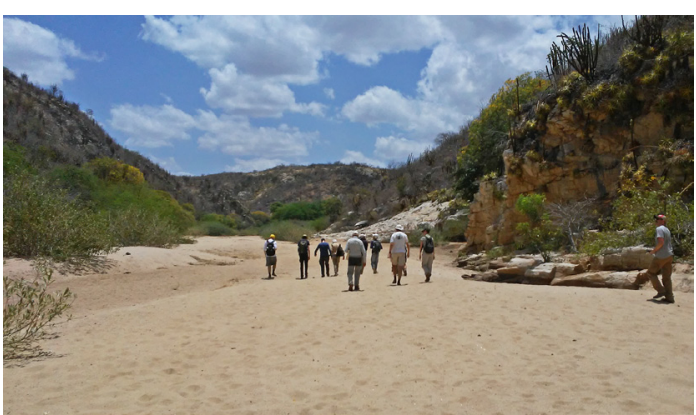

Figure 15 - Monocots VI attendees visiting an area of inselbergs within the Caatinga, in the Seridó region.

and Capim Macio Publishers. The National Council for Scientific and Technological Development (CNPq 437706/2016-8 e 407241/2017-5), National Council for the Improvement of Higher Education (CAPES), São Paulo Research Foundation (FAPESP 18/06926-6), and the Bromeliad Society International provided critical financial support. We thank Klei Sousa and Fernando Sousa for illustrating and creating the visual identity of the event and Alan Herndon (Bromeliad Society International) for help with proofreading the event website. Managers of the reserves APA de Jenipabu, Parque Estadual das Dunas, Estação Ecológica do Seridó are acknowledged for visitation permits. The editorial staff of Rodriguésia (especially Vidal Mansano and Karen De Toni) and Editora da UFRN (Helton Rubiano) provided an important assistance with publications.

\section{References}

Campbell L, Davis JI, Meerow AW, Naczi RFC, Stevenson DW \& Thomas WW (2017) Diversity and Phylogeny of the Monocotyledons:

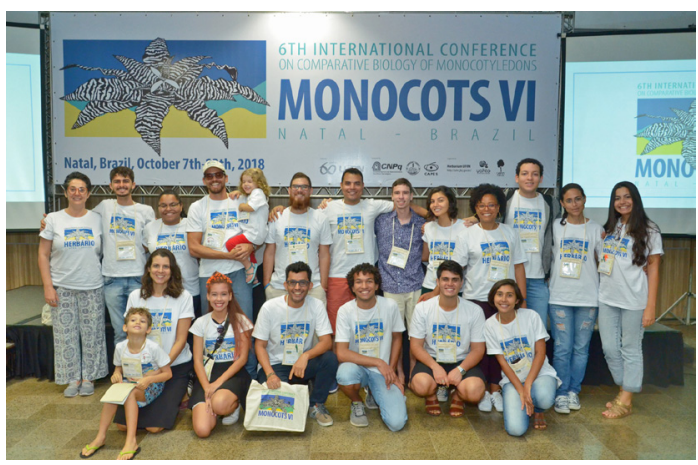

Figure 16 - Part of the Monocots VI team and UFRN herbarium students. 
contributions from Monocots V. Memoirs of The New York Botanical Garden 118: 1-172.

Columbus JT, Friar EA, Porter JM, Prince LM \& Simpson MG (2006) Monocots: comparative Biology and Evolution (excluding Poales). Aliso 22: 1-735.

Columbus JT, Friar EA, Porter JM, Prince LM \& Simpson MG (2007) Monocots: comparative Biology and Evolution - Poales. Aliso 23: 1-682.

Rudall PJ, Cribb PJ, Cutler D \& Humphries CJ (1995) Monocotyledons: systematics and evolution. Vols. 1, 2. Royal Botanic Gardens, Kew, London. 772p.

Seberg O, Balslev H, Barfod AS, Borchsenius F, Frederiksen S, Friis I, Johansen BB, Petersen G \& Rasmussen FN (2008) Monocots IV - programme. Natural History Museum of Denmark, University of Copenhagen, Copenhagen. 28p.
Versieux LM \& Clark LG (2019)Abstracts of the Monocots VI. EDUFRN, Natal. 232p. Available at $<$ https:// repositorio.ufrn.br/jspui/handle/123456789/27097>. Access on 23 May 2019.

Versieux LM, Palma-Silva C, Wendt T \& Mercier H (2018) Report from the $2^{\text {nd }}$ World Congress of Bromeliaceae Evolution - BromEvo II (Natal, Brazil, 2018). Botanical Journal of the Linnean Society 192: 587-588. DOI: <https://doi.org/10.1093/botlinnean/boaa002>.

Wilson KL \& Morrison DA (2000) Monocots systematics and evolution. CSIRO Publishing, Collingwood, Victoria. 738p.

Woudstra Y \& Veltman M (2018). Building the whole from its parts. Available at $<$ https://www.plantid.uio. no/news-and-events/blog/building-the-whole-fromits-parts.html>. Access on 9 March 2019. 